\title{
Developing User-Friendly Habitat Suitability Tools from Regional Stream Fish Survey Data
}

\author{
Troy G. Zorn* \\ Michigan Department of Natural Resources and Environment, Marquette Fisheries Research Station, \\ 484 Cherry Creek Road, Marquette, Michigan 49855, USA
}

\section{Paul W. Seelbach}

U.S. Geological Survey, Great Lakes Science Center, 1451 Green Road, Ann Arbor, Michigan 48105-2807, USA

\author{
Michael J. Wiley \\ School of Natural Resources and Environment, University of Michigan, 170 Dana Building, Ann Arbor, \\ Michigan 48109-1115, USA
}

\begin{abstract}
We developed user-friendly fish habitat suitability tools (plots) for fishery managers in Michigan; these tools are based on driving habitat variables and fish population estimates for several hundred stream sites throughout the state. We generated contour plots to show patterns in fish biomass for over 60 common species (and for 120 species grouped at the family level) in relation to axes of catchment area and low-flow yield ( $90 \%$ exceedance flow divided by catchment area) and also in relation to axes of mean and weekly range of July temperatures. The plots showed distinct patterns in fish habitat suitability at each level of biological organization studied and were useful for quantitatively comparing river sites. We demonstrate how these plots can be used to support stream management, and we provide examples pertaining to resource assessment, trout stocking, angling regulations, chemical reclamation of marginal trout streams, indicator species, instream flow protection, and habitat restoration. These straightforward and effective tools are electronically available so that managers can easily access and incorporate them into decision protocols and presentations.
\end{abstract}

Management of stream fisheries at the local scale would benefit from habitat suitability tools (i.e., quantitative fish-habitat relationships) derived from the synthesis of existing local and regional data. Existing regional or national data sets, such as habitat suitability index (HSI) models (e.g., Raleigh et al. 1986) may lack samples for a particular stream type or may include such a broad array of hydrologic types that data resolution is inadequate for supporting decisions at a local scale. For example, a national sample of trout streams (e.g., Poff and Ward 1989) may include rivers where thermal habitat conditions are driven by mountain elevations, snowmelt, flow releases from hydropower dams, or groundwater inputs, even though only a subset of these factors may significantly influence streams in a particular region (e.g., groundwater inputs are key in glaciated Midwestern states). On the other hand, fish-habitat relationships (models) from detailed, location-specific studies may be difficult to apply to other regions if stream conditions differ (sensu Fausch et al. 1988) or if making predictions of fish density requires additional resources (e.g., software, technical expertise, or funding). Although much of the fishery management effort is carried out by state agencies, summaries relating fish density and habitat data on a statewide scale often are lacking, are not standardized (gear specific), or have yet to be synthesized.

*Corresponding author: zornt@ @michigan.gov

Received April 9, 2010; accepted November 8, 2010 
Through the Michigan Rivers Inventory (MRI) project (Seelbach and Wiley 1997), data describing stream and river fish assemblages and habitat attributes at several hundred sites across the state have been compiled. These data have been used to develop models for understanding and classifying systems (Wiley and Seelbach 1997; Zorn et al. 2002; Seelbach et al. 2006). The models have also enabled prediction of streamflow characteristics (Seelbach et al. 2010), summer water temperatures (Wehrly et al. 1997), and fish assemblages (Zorn et al. 2004; Steen et al. 2008) for rivers within the state. The MRI database would also readily lend itself to the development of simple decision-support tools (e.g., plots) relating fish density to habitat, but such a synthesis has not previously been attempted.

Previous studies have demonstrated that spatial patterns in fish distribution and abundance in glaciated Midwestern streams can often be explained by relatively few habitat variables. Such driving variables integrate features of the landscape at the catchment scale and more localized scales and serve to index habitat features that directly influence fishes. Stream size, measured as catchment area (CA), provides a measure of habitat volume, indexes water temperature and temporal stability, and is a welldocumented correlate of species distribution and abundance in the Upper Midwest (e.g., Hynes 1972; Lyons 1996; Zorn et al. 2002; Zorn and Wiley 2006; Steen et al. 2008). Low-flow yield (LFY), defined as the $90 \%$ exceedance flow divided by CA, is a measure of groundwater contribution to streams and serves as an index of important habitat characteristics. For example, summer conditions in high-LFY streams are characterized by cooler stream temperatures, increased hydrologic stability, higher current velocities, and lower percentages of fine substrates (Hendrickson and Doonan 1972; Meisner et al. 1988; Poff and Allan 1995; Zorn et al. 2002; Zorn and Wiley 2006). In glaciated landscapes of the Great Lakes region, stream environments and fish communities can vary substantially across the landscape due to local variation in geology and resulting groundwater inputs to streams (Wiley et al. 1997; Baker et al. 2003). Summer temperature is one of the major factors affecting fish growth (Brett 1979), survival (Smale and Rabeni 1995a), and distribution (Magnuson et al. 1979; Meisner et al. 1987; Smale and Rabeni 1995b; Lyons 1996; Wehrly et al. 2003; Zorn et al. 2004; Steen et al. 2008) throughout the Midwest and temperate regions of the world. Collectively, the CA, LFY, and summer temperature provide a simple yet useful framework for describing the physical environment and energetic constraints for fish populations at individual river sites (Zorn et al. 2002; Zorn and Wiley 2006). Our objective was to develop user-friendly tools that can be used by Michigan fishery managers and that relate these driving habitat variables to densities of fish species that commonly occur in the state. Our approach to developing these tools is presented as an example for fisheries managers who seek to construct similar tools and who have access to regional fisheries and habitat survey data.

\section{METHODS}

Study area.-Data were obtained for this study from several hundred stream sites scattered across Michigan. The entire state was influenced by Pleistocene glaciation and, except for portions of the Upper Peninsula, is covered by unconsolidated glacial deposits ranging in texture from coarse sands and gravels (associated with moraines and glacial outwash) to clays from former glacial lake beds. The thickness of these deposits ranges from a few feet to several hundred feet. The texture, depth, and associated hydrologic properties of these deposits have a strong influence on river flow, channel conditions, and fish assemblages (Hendrickson and Doonan 1972; Zorn et al. 2002; Seelbach et al. 2010).

Data sources.-Fisheries survey data for 515 stream sites in Michigan's Lower Peninsula were obtained from the MRI database (Seelbach and Wiley 1997), and data for 46 sites on Upper Peninsula streams were obtained from one of the MRI's companion studies (Baker 2006). From 1982 to 2001, surveys were conducted in wadeable streams and small river reaches during the summer. Density estimates were available for the entire fish assemblage at 297 sites sampled using means of rotenone or multipass electrofishing depletion surveys, and mark-recapture estimates for salmonids were obtained at an additional 80 sites (Figure 1). In addition, thorough electrofishing surveys at 184 sites were used to document species absences but could not be used to provide density estimates of the species that were present. Seelbach et al. (1988) and Seelbach and Wiley (1997) provide greater detail regarding fish sampling techniques and computation of abundance estimates.

The large number of sites with fish density data provided a representative sample of Michigan streams, but there are a few caveats. Small streams (i.e., CA $<10 \mathrm{mi}^{2}$ ) and Upper Peninsula waters were somewhat undersampled relative to their abundance on the landscape (Figure 1). Fish density estimates from rotenone surveys may represent only about $75 \%$ of actual values because of sampling inefficiency (Seelbach et al. 1994). To obtain density estimates for all species captured, we assumed equal catchability of all fishes at electrofishing depletion sites (Zippin 1958), but there was undoubtedly variation in catchability among species. While no replicate samples occurred at specific sites, the data set captured temporal variation to some degree by covering a broad sampling period. Therefore, although any individual sample may not perfectly represent a site's typical fish assemblage, the existence of fish density data from the several hundred sites essentially provided replicate samples for most types of Michigan rivers and streams. In addition, we expected density patterns for most species at the statewide scale to be distinct enough (e.g., contrasts of high density versus low density versus zero density) that sampling-induced biases would not significantly alter our findings.

Three types of stream habitat data were used for this study. Geographical information systems (GIS) techniques were used to measure $\mathrm{CA}$ as the entire upstream drainage area for each site. 
TABLE 1. Species and taxonomic groups used in surface plots of fish density versus habitat variables. Species are listed under the numbered taxonomic group to which they belong. Densities of less-common species (not listed) were included with their corresponding taxonomic group.

\begin{tabular}{|c|c|c|c|}
\hline Group number & Species or group name & Group number & Species or group name \\
\hline \multirow[t]{9}{*}{1} & Shiners & 9 & Pikes \\
\hline & Spotfin shiner Cyprinella spiloptera & & Redfin pickerel Esox americanus \\
\hline & Common shiner Luxilus cornutus & & Northern pike Esox lucius \\
\hline & Striped shiner Luxilus chrysocephalus & 10 & Salmonids \\
\hline & Redfin shiner Lythrurus umbratilis & & Brook trout Salvelinus fontinalis \\
\hline & Golden shiner Notemigonus crysoleucas & & Brown trout Salmo trutta \\
\hline & Rosyface shiner Notropis rubellus & & Coho salmon Oncorhynchus kisutch \\
\hline & Sand shiner Notropis stramineus & & Rainbow trout $O$. mykiss \\
\hline & Mimic shiner Notropis volucellus & & Chinook salmon $O$. tshawytscha \\
\hline \multirow[t]{3}{*}{2} & Minnows & 11 & Sculpins \\
\hline & Bluntnose minnow Pimephales notatus & & Mottled sculpin Cottus bairdii \\
\hline & Fathead minnow Pimephales promelas & & Slimy sculpin Cottus cognatus \\
\hline \multirow[t]{5}{*}{3} & Chubs and stonerollers & 12 & Sunfishes \\
\hline & Central stoneroller Campostoma anomalum & & Rock bass Ambloplites rupestris \\
\hline & Creek chub Semotilus atromaculatus & & Green sunfish Lepomis cyanellus \\
\hline & Hornyhead chub Nocomis biguttatus & & Bluegill Lepomis macrochirus \\
\hline & River chub Nocomis micropogon & & Longear sunfish Lepomis megalotis \\
\hline \multirow[t]{2}{*}{4} & Carp and goldfish & & Pumpkinseed Lepomis gibbosus \\
\hline & Common carp Cyprinus carpio & & Smallmouth bass Micropterus dolomieu \\
\hline \multirow[t]{4}{*}{5} & Daces & & Largemouth bass Micropterus salmoides \\
\hline & Eastern blacknose dace Rhinichthys atratulus & & White crappie Pomoxis annularis \\
\hline & Longnose dace $R$. cataractae & & Black crappie Pomoxis nigromaculatus \\
\hline & Northern redbelly dace Phoxinus eos & 13 & Perches \\
\hline \multirow[t]{6}{*}{6} & Suckers & & Walleye Sander vitreus \\
\hline & Quillback Carpiodes cyprinus & & Yellow perch Perca flavescens \\
\hline & White sucker Catostomus commersonii & 14 & Darters $^{\mathrm{b}}$ \\
\hline & Lake chubsucker Erimyzon sucetta & & Logperch Percina caprodes \\
\hline & Northern hog sucker Hypentelium nigricans & & Blackside darter Percina maculata \\
\hline & Spotted sucker Minytrema melanops & & Greenside darter Etheostoma blennioides \\
\hline \multirow[t]{6}{*}{7} & Redhorses $^{\mathrm{a}}$ & & Rainbow darter Etheostoma caeruleum \\
\hline & Silver redhorse Moxostoma anisurum & & Johnny darter Etheostoma nigrum \\
\hline & Black redhorse Moxostoma duquesnei & & \\
\hline & Golden redhorse Moxostoma erythrurum & & Species that were not pooled: \\
\hline & Shorthead redhorse Moxostoma macrolepidotum & & Bowfin Amia calva \\
\hline & Greater redhorse Moxostoma valenciennesi & & Gizzard shad Dorosoma cepedianum \\
\hline \multirow[t]{8}{*}{8} & Catfishes & & Central mudminnow Umbra limi \\
\hline & Black bullhead Ameiurus melas & & Pirate perch Aphredoderus sayanus \\
\hline & Brown bullhead Ameiurus nebulosus & & Burbot Lota lota \\
\hline & Yellow bullhead Ameiurus natalis & & Brook silverside Labidesthes sicculus \\
\hline & Channel catfish Ictalurus punctatus & & Brook stickleback Culaea inconstans \\
\hline & Stonecat Noturus flavus & & Hybrid sunfish \\
\hline & Tadpole madtom Noturus gyrinus & & Freshwater drum Aplodinotus grunniens \\
\hline & Flathead catfish Pylodictis olivaris & & \\
\hline
\end{tabular}

\footnotetext{
${ }^{\mathrm{a} A l l}$ redhorses were also included in group 6 (suckers)
}

${ }^{\mathrm{b}}$ All darters were also included in group 13 (perches). 


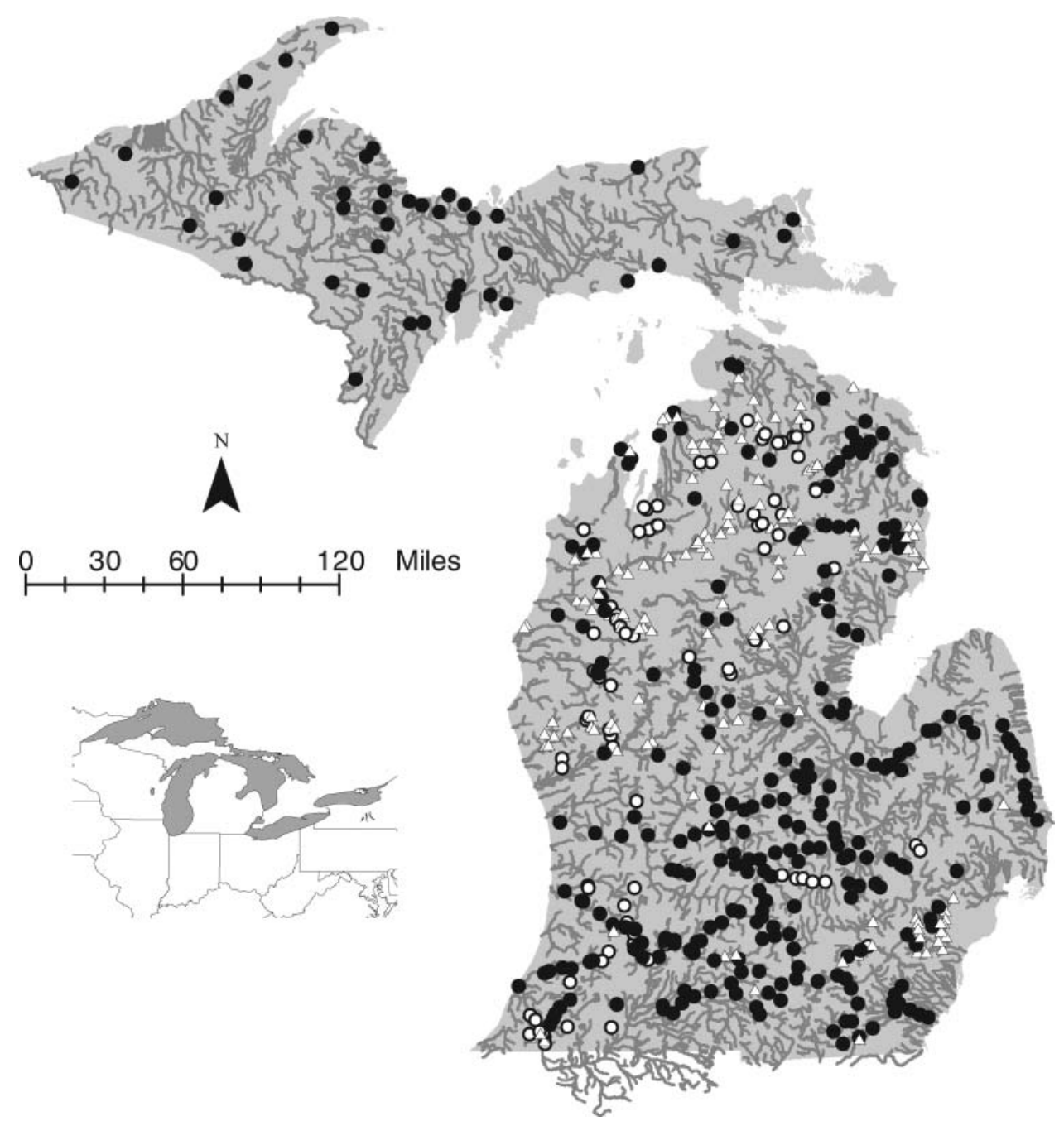

FIGURE 1. Sites on Michigan streams with fish density data for salmonids ( $n=80$ sites; open circles) and for the entire fish assemblage $(n=297$ sites; solid circles). Species absences were documented at an additional 184 sites (open triangles). All fish sampling occurred during the summer months. Inset shows location of Michigan and surrounding states relative to the Great Lakes.

Annual $90 \%$ exceedance flow values were also obtained from the studies by Seelbach and Wiley (1997) and Baker (2006) and consisted of measurements from U.S. Geological Survey gaging stations at 87 sites and regression model predictions for the remaining sites (Baker 2006; Seelbach et al. 2010). The LFY was computed for a site by dividing the $90 \%$ annual exceedance flow by CA. Stream temperature data for July were obtained for 347 sites and consisted of hourly measurements at the majority of sites and weekly maximum and minimum readings at the remaining sites. We focused on July because it is usually the warmest month in Michigan and is a time when stream temperatures, thermal stress, and distinction among stream types are highest. From these data, we computed the July mean temperature, which (depending upon the data source) was either an average of the hourly readings or an average of the weekly readings. To determine the comparability of July mean temperature values calculated from these two types of data, we used hourly temperature data from a subsample of sites and compared July mean temperature values computed with both methods. We found that these two calculations produced values that were nearly identical $(r=0.995)$. We also computed the July weekly temperature range, which was the average of the differences between each week's maximum and minimum temperatures. July temperature values were predicted for 214 sites from which measurements were not available (Wehrly et al. 1997), although most of these sites served only to document species absences. July temperature values were measured at 314 of the 377 sites where fish density estimates were made and at 33 of the 184 sites that were used only to document species absences.

Data analysis.-The data were analyzed several ways to depict relationships between species density and habitat. For species and select groups of taxa (Table 1), we generated contour plots to show statewide patterns in fish biomass in relation to axes of (1) LFY and CA and (2) mean and weekly range of 

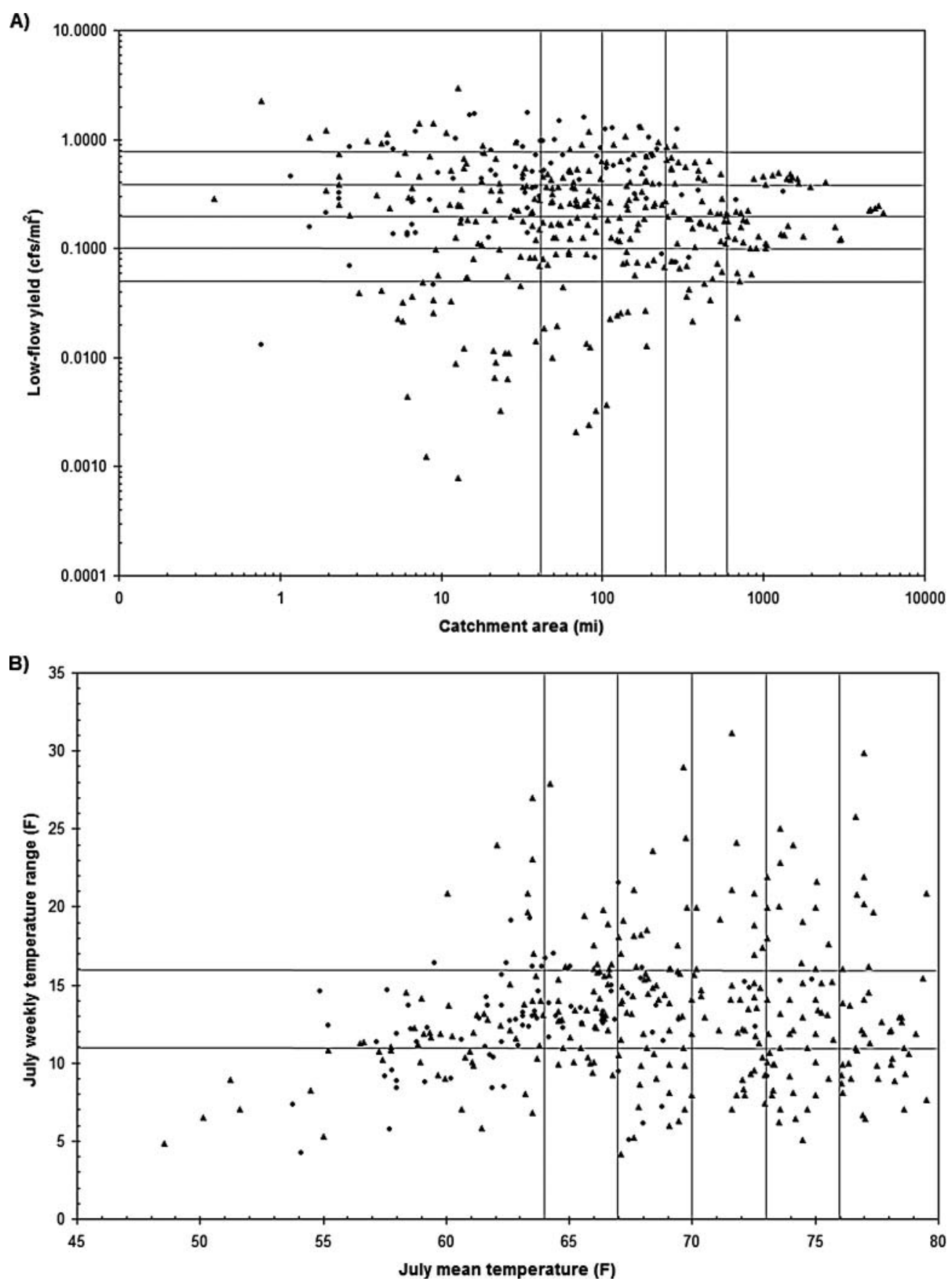

FIGURE 2. Data summary grids used to summarize species density and habitat conditions at Michigan Rivers Inventory sites along the axes of (A) low-flow yield and catchment area and (B) mean and weekly range in July temperature $\left({ }^{\circ} \mathrm{F}\right)$. Lines define boundaries of cells for which statistical summaries of habitat variable and fish density values were calculated. Symbols distinguish between sites where fish were sampled by mark-recapture methods (circles) and sites where rotenone or multipass depletion methods were used (triangles).

July temperatures. This was accomplished by describing subsets of MRI sites that met particular LFY, CA, or temperature criteria. We first plotted all study sites along the axes of LFY and $\mathrm{CA}$ and then divided the plots into cells that provided the analytic "grain" for summarizing the data (Figure 2). Cell boundaries were placed so that each cell generally contained enough sites to provide a robust characterization of fish abundance for the given set of conditions. We also attempted to achieve uniform spacing of cell boundary lines along each axis. Using the cells as a sampling frame, we selected all sites that met the criteria of each cell and computed average values for fish density and the selected habitat conditions. The average values for the 
habitat variables were then plotted on the same $x-y$ axes, and the average fish density values were used to provide the shaded contours. This analysis was first done with LFY and CA as axes and then was repeated with mean and weekly range in July temperature as axes. This analysis was also performed for numerical density of salmonids since these species are of particular interest to fishery managers in Michigan.

We think the plots of fish abundances on these habitat axes likely reflect long-term average population levels since the abundances were averaged from many similar sites sampled during different years. Population estimates from individual fish surveys may differ considerably from these values because of natural fluctuations in population levels. For example, replicate rotenone samples available from seven warmwater stream sites in Michigan (T. G. Zorn, unpublished data) showed up to threefold differences in abundance levels of the more common fish species (i.e., abundances $>10$ lb/acre). Wiley et al. (1997) suggested that 15-20 years of population estimate data may be needed to accurately characterize the long-term mean and variance of trout populations in hydrologically stable, groundwaterfed Michigan streams. As such long-term data do not exist for most Michigan streams, pooling data from similar sites allowed us to develop initial estimates of the mean and variance in fish populations associated with different stream conditions.

We also produced scatter plots depicting the numerical density of brown trout and brook trout in relation to July mean temperature for Michigan streams. The wedge-shaped distribution of data relating July mean temperature to trout density indicated that July mean temperature is an index of conditions that become limiting to trout (Terrell et al. 1996; Thompson et al. 1996; Wehrly et al. 2007). To demonstrate this relation, we visually fit a line along the upper portion of the data to show the relation between maximum potential brown trout density and July mean temperature.

\section{RESULTS}

Our statewide habitat suitability models were based upon an extremely broad array of rivers for which attribute values spanned several orders of magnitude. Catchment area ranged from 0.4 to $5,513 \mathrm{mi}^{2}$ ( stream width $=2-350 \mathrm{ft}$ ), LFY ranged from 0.0008 to $2.93 \mathrm{ft}^{3} \cdot \mathrm{s}^{-1} \cdot \mathrm{mi}^{-2}$, July mean temperature ranged from $48^{\circ} \mathrm{F}$ to $80^{\circ} \mathrm{F}$, and July weekly temperature ranged from $4^{\circ} \mathrm{F}$ to $31^{\circ} \mathrm{F}$. Our sample included some of the most hydrologically stable coldwater streams in the United States (Zorn and Sendek 2001) as well as flashy, warmwater rivers that drain clay landscapes and urban environments (Seelbach et al. 2010). The regional variation in stream thermal regimes covered in this study is among the highest reported in the literature (Wehrly et al. 2003). Low-flow yield and CA were closely tied to patterns in July mean temperature (Figure 3). Total fish density at individual sites ranged from 5 to 1,004 lb/acre, and species richness varied from 1 to 40 per site.

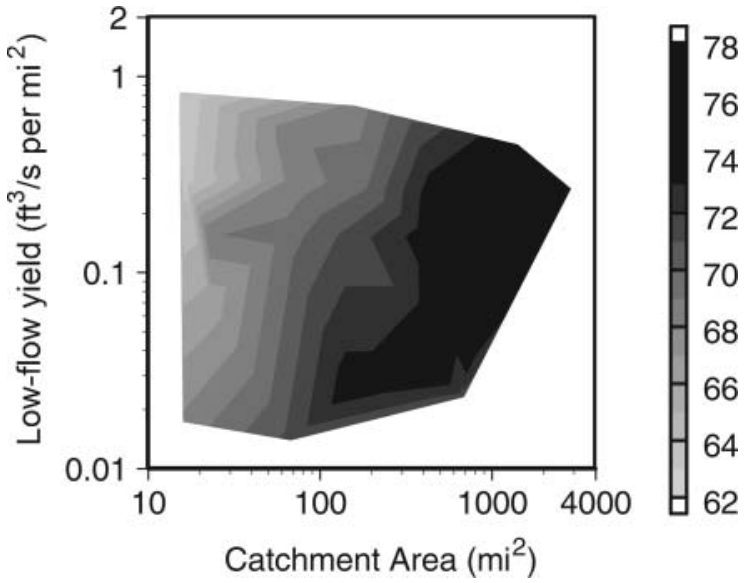

FIGURE 3. Relationship between July mean temperature $\left({ }^{\circ} \mathrm{F}\right.$; depicted by differences in shading), catchment area, and low-flow yield for Michigan rivers.

The plots are useful for distinguishing habitat affinities among species, comparing river sites, and assessing potential response of local systems to various management activities. Some species, such as brook trout and smallmouth bass, have fairly restricted stream size and hydrology "suitabilities," whereas other fishes (e.g., white sucker and rock bass) can do well under a broad array of conditions and have less-distinctive abundance peaks (Figure 4). Similar patterns can be seen at higher taxonomic levels: salmonids are most abundant in rivers with high groundwater inputs, daces become more abundant as LFY values decrease, and suckers and catfishes are more prominent in larger rivers with lower LFYs (Figure 5). Such relationships provide the quantitative basis for assessing the potential of a river reach to support different fish species and for describing how existing impairments at individual sites affect fish populations (e.g., Figures 6, 7).

A complete set of full-color plots for species and taxa examined in this study (Table 1) and the fish assemblage attributes of species richness and total biomass can be obtained from Zorn et al. (2009; available online - the web address is provided in the reference). To facilitate comparisons with specific sites on Michigan rivers, the LFY, CA, and July temperature values for sites with fish density estimates used in this study can be obtained from the primary author (T.G.Z.). Values for the remainder of Michigan stream reaches have been estimated and are available from the Michigan Department of Natural Resources (MDNR) Institute for Fisheries Research (IFR), Ann Arbor (Brenden et al. 2006).

\section{DISCUSSION}

The relationships we depict are analogous to traditional HSI plots in that they show conditions where species do well, as indexed by observed fish density; however, the relationships presented here differ from traditional HSIs in several respects. Traditional HSI studies often involve specialized surveys to 

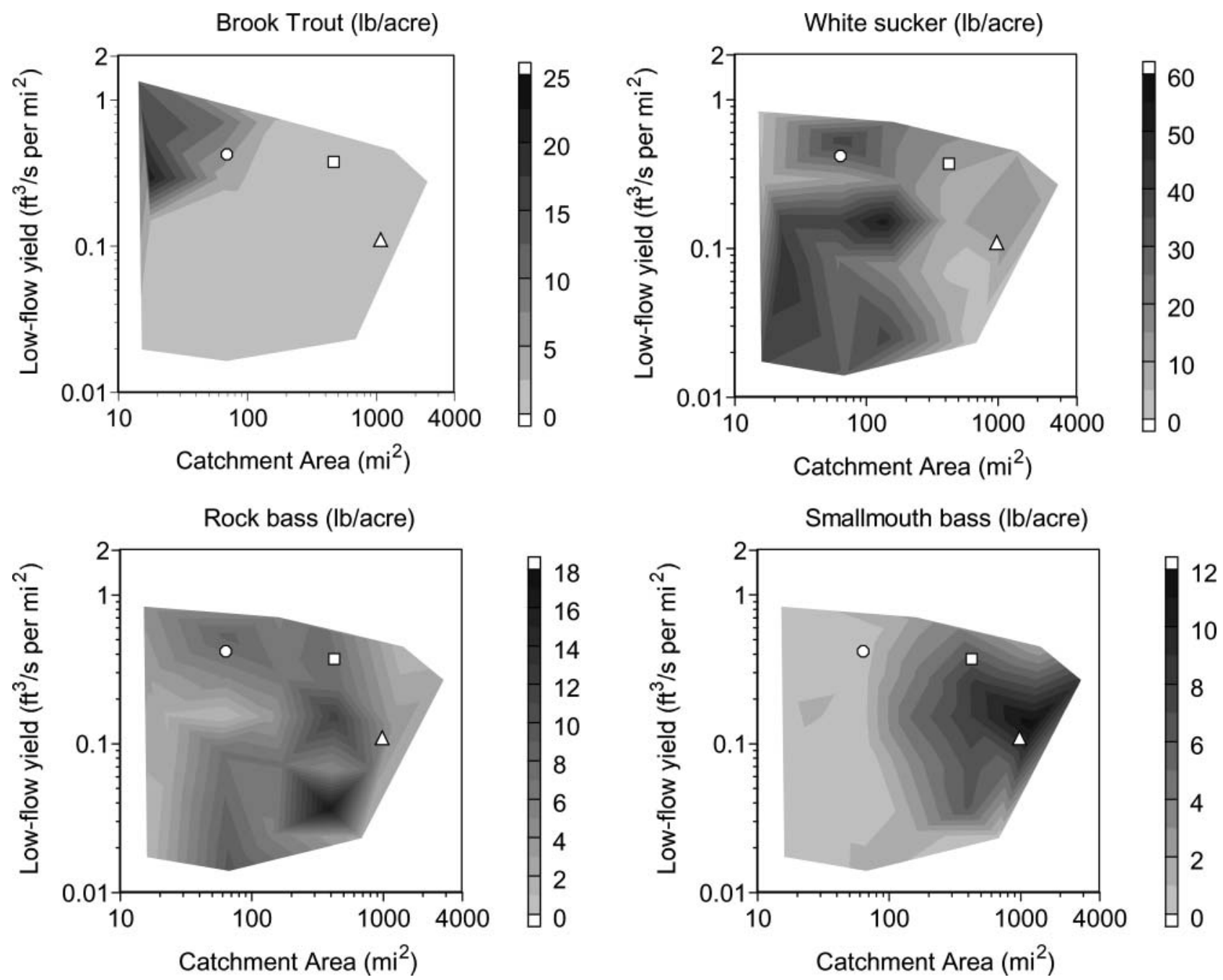

FIGURE 4. Average density (depicted by differences in shading) of brook trout, white suckers, rock bass, and smallmouth bass in relation to low-flow yield and catchment area in Michigan streams. Conditions are shown on each plot for the Iron River at Iron River (circle), the Flat River at Belding (square), and the River Raisin at Monroe (triangle). Note that the density scales differ among graphs.

assess microhabitat use of particular fish species and life stages (e.g., Raleigh et al. 1986; Aadland and Kuitunen 2006), and accomplishing these studies can be difficult due to the time and labor constraints associated with data collection. We instead used existing general fish survey data to develop a comprehensive set of HSI relationships for species that are typically encountered in Michigan. However, our HSIs only assess the general suitability of a reach's habitat for species abundance rather than its suitability for specific life stages. Unlike traditional HSI models, which typically score site conditions on a scale from 0 to 1 based upon the site's suitability, we used measured fish densities because they are more readily interpreted and understood by the public. In addition, because fish density values are not scaled relative to data from other sites as would occur in a 0-1 rating system, the relationships we present should be relatively robust to future additions of survey data.
Our choice of focal habitat variables also differed from most other HSI studies. Most HSI studies typically include microhabitat-scale variables (e.g., depth, velocity, substrate, or cover), whereas we focused on a few large-scale driving variables that shape many site-measured habitat variables and that have been shown in numerous regional studies to be important predictors of fish distribution and abundance. River size, summer temperature, and low-flow hydrology variables (or combinations of these) are key predictors of river fish distribution and abundance in various regions of Europe (e.g., Sweden: Degerman and Sers 1993; France: Lamouroux et al. 1999) and North America, including Wyoming (Rahel and Hubert 1991), Wisconsin (Lyons 1996), Oregon Waite and Carpenter 2000), Kansas (Gido et al. 2006), Ontario (Stanfield et al. 2006), and Michigan (Steen et al. 2008). In addition, these driving variables can often be measured or modeled from commonly available 

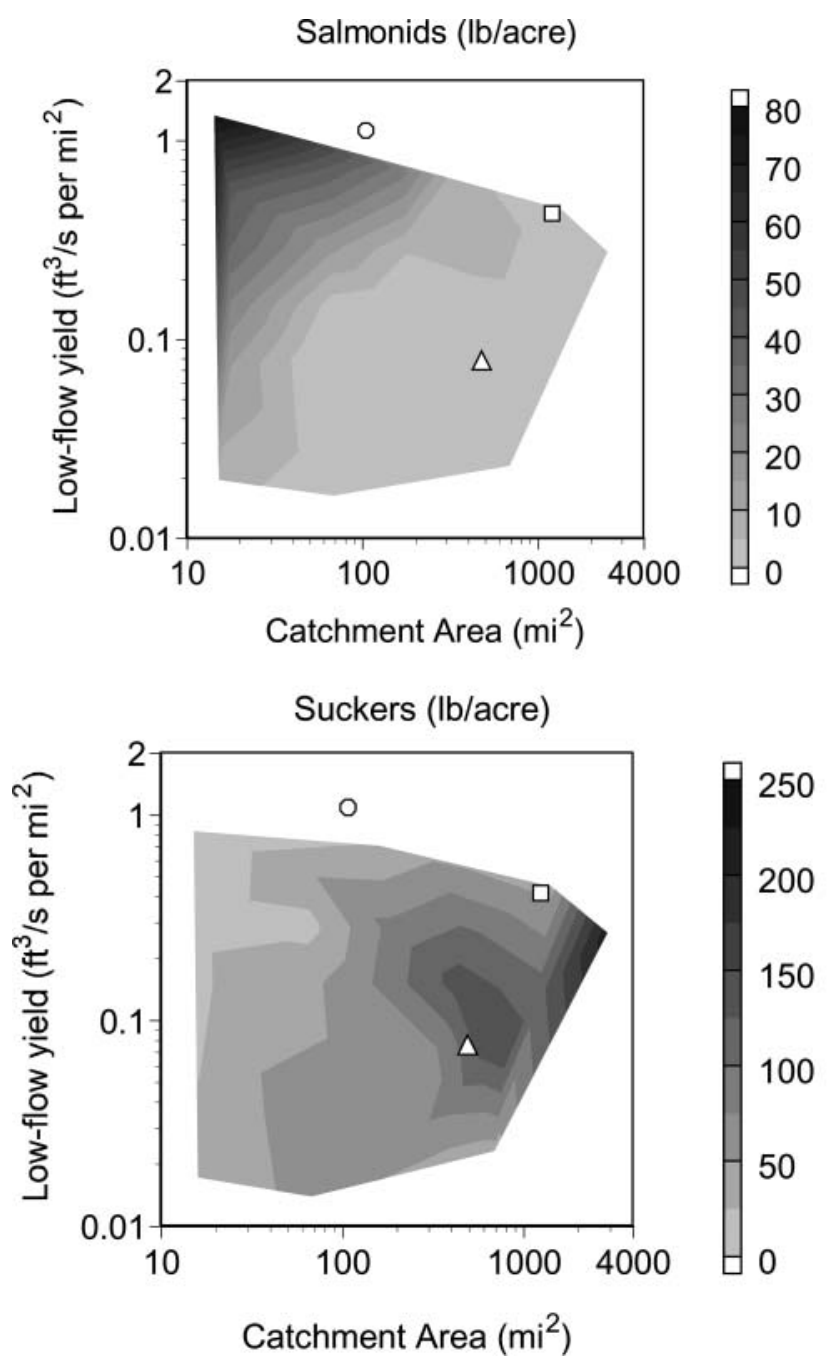
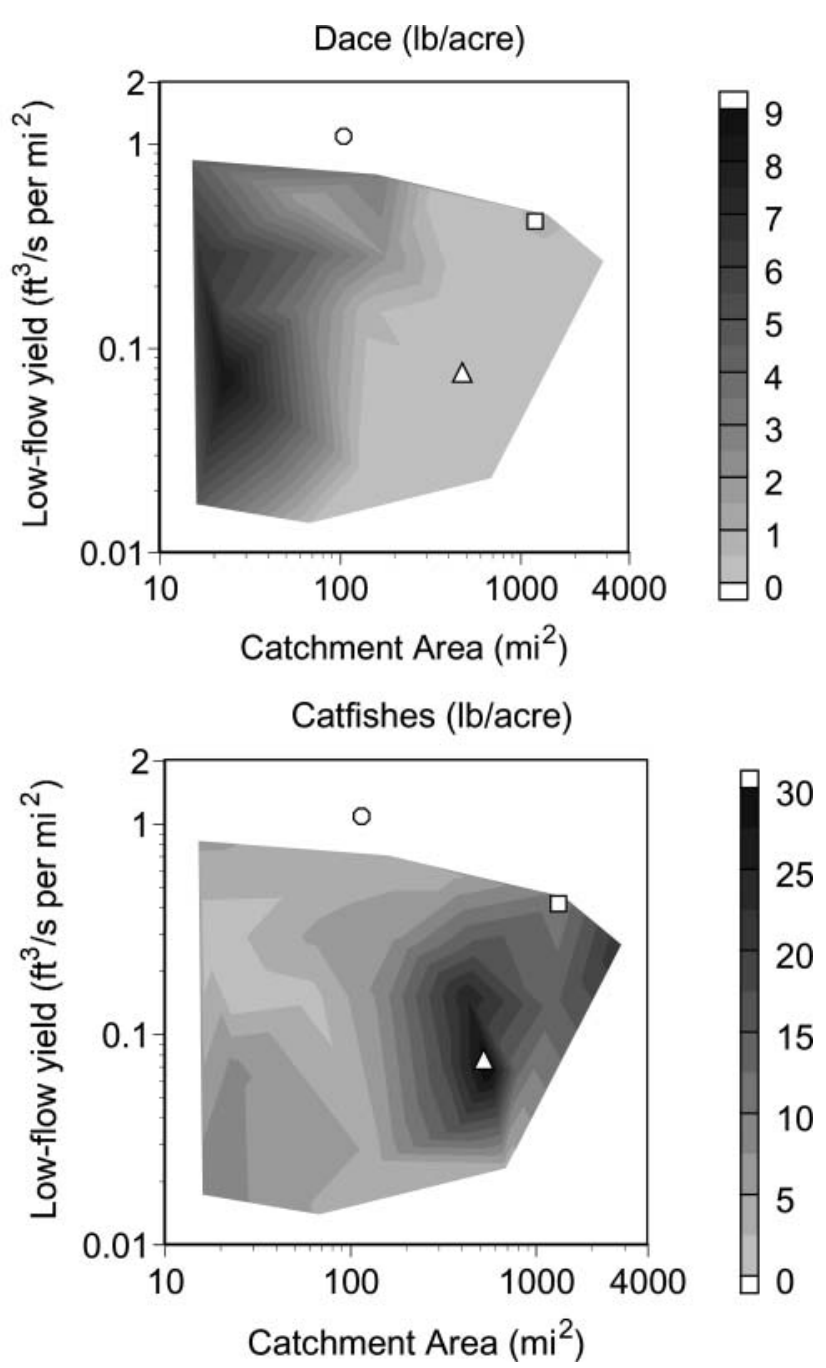

FIGURE 5. Average density (depicted by differences in shading) of salmonids, daces, suckers, and catfishes in relation to low-flow yield and catchment area in Michigan streams. Conditions are shown on each plot for the Manistee River at Grayling (circle), the Maple River (a Grand River tributary) at Maple Rapids (triangle), and the Manistique River at Manistique (square). Note that the density scales differ among graphs.

empirical measurements and GIS-based landscape data layers (Wehrly et al. 1997; Seelbach et al. 2010). Because our study has a broad focus, our models are better suited to addressing intermediate-scale (e.g., reach- or segment-scale) questions about the suitability of river habitats for fish populations than to addressing questions related to a fish's distribution within a stream reach (Rabeni and Sowa 1996). Nevertheless, we believe that these HSI relationships will prove valuable to fishery managers in Michigan since many management issues occur at these intermediate scales (Seelbach et al. 2006).

\section{Management Applications}

This analysis fills a basic need of fishery managers, namely to have regionally based, data rich, uncomplicated decision support tools for showing constituents and the public the biological basis behind local river management decisions. The graphs provide a solid base for supporting management decisions because the relationships are based upon observations from several hundred sites and because multiple observations often occur for a given set of conditions. Fish-habitat relationships are especially strong when a graph for a given species or taxon shows one optimal set of habitat conditions associated with peak fish density, despite the wide range of habitat conditions available across the state. Habitat attributes that are chosen as axes for the plots can be readily used to plot conditions for a specific river site of interest, assess its suitability for various fish species, and compare and contrast the site with other sites and rivers. Fishery managers can simply "cut and paste" the electronically available plots (see the Zorn et al. 2009 reference for the web address) into presentations and reports and use them to assess the fish species potential for any site statewide.

This analysis provides useful benchmarks with which to assess the potential of nearly any Michigan river for fishes because we focused on relating species densities to limiting factors (e.g., 

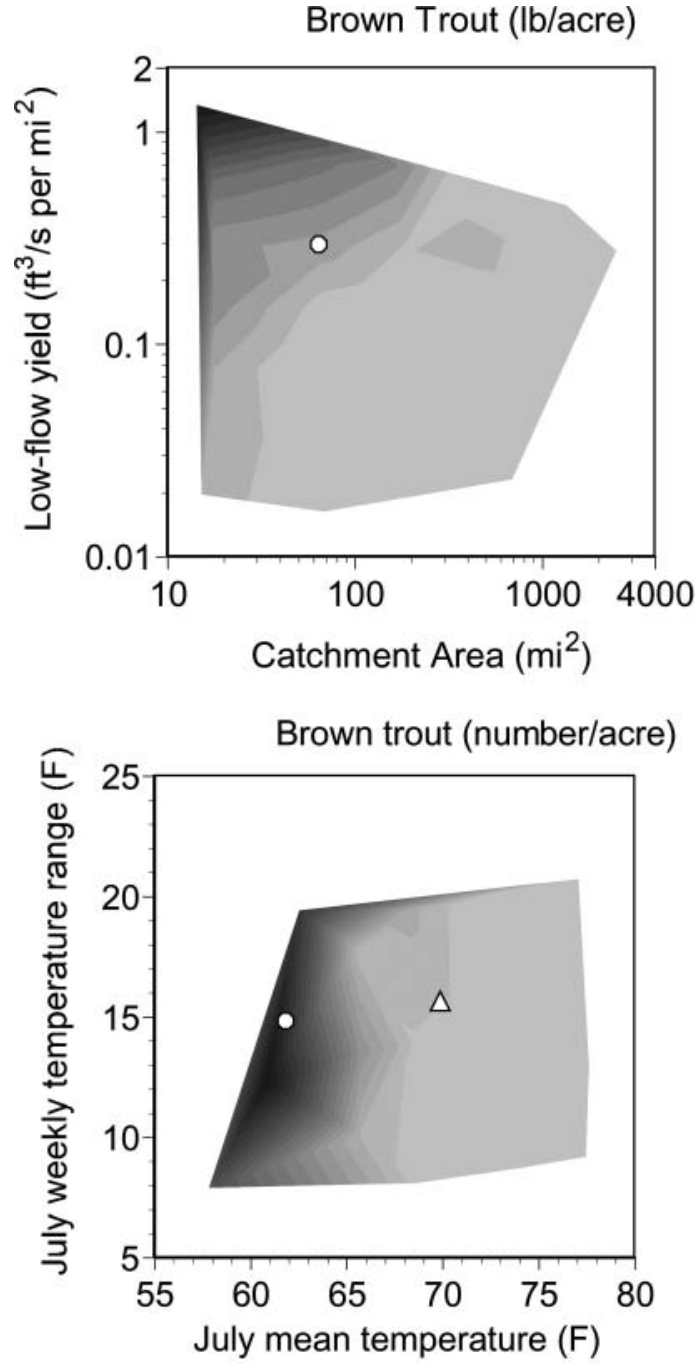
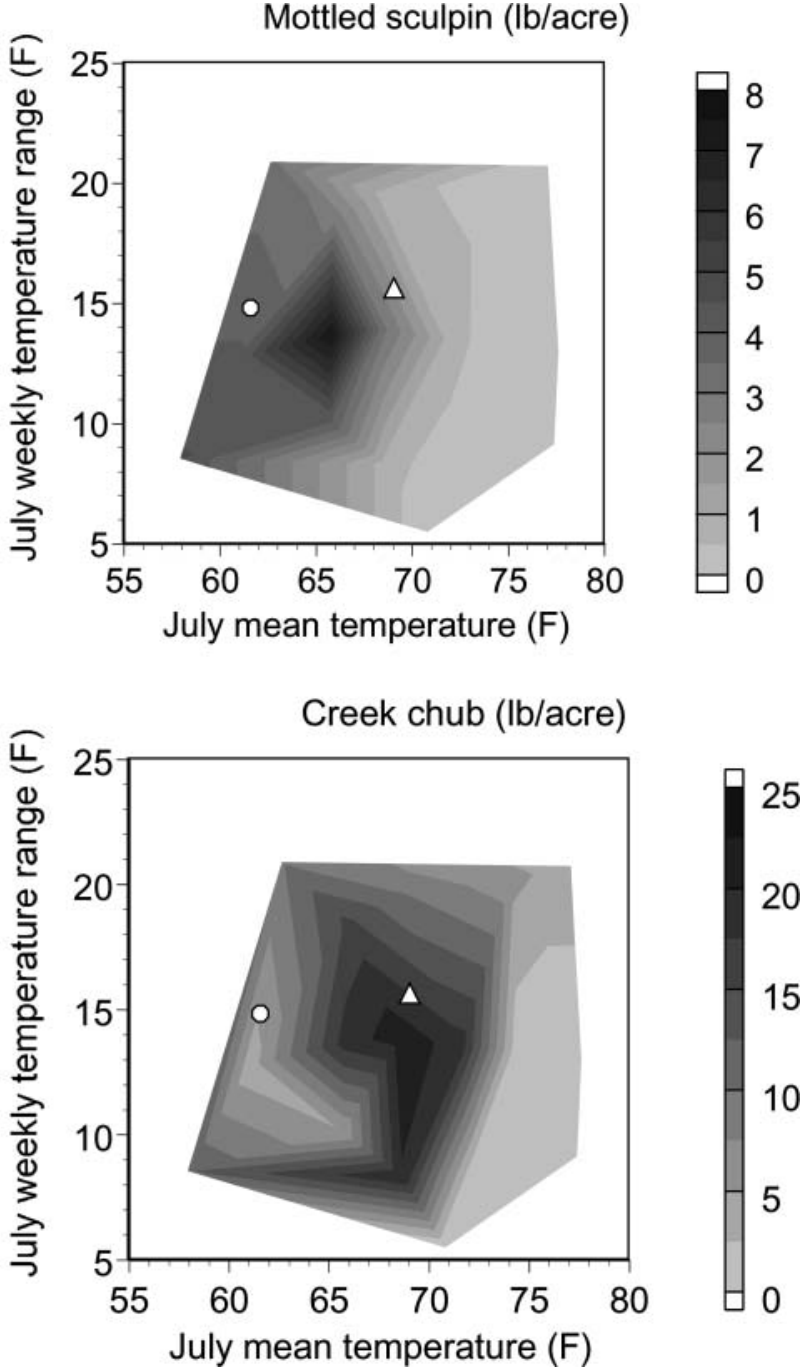

FIGURE 6. Relationships of biomass density (brown trout, creek chub, or mottled sculpin) or numerical density (brown trout) to low-flow yield, catchment area, and July temperature $\left({ }^{\circ} \mathrm{F}\right.$ ) variables in Michigan streams. Density is depicted by differences in shading. Conditions of the Middle Branch River upstream (circle) and downstream (triangle) from Marion Mill Pond are shown on temperature plots. Low-flow yield and catchment area conditions are essentially identical since upstream and downstream sites are less than $1 \mathrm{mi}$ apart. Note that the density scales differ among graphs.

temperature) and variables (i.e., LFY and CA) that are well correlated with key aspects of habitat (e.g., temperature, depth, and velocity) and species distributions in Michigan (Bailey et al. 2004; Zorn et al. 2004). The statewide relationships between these habitat factors and fish density can be coupled with sitebased data to better identify those factors that may be limiting a particular population's abundance at a site. In the paragraphs that follow, we provide examples demonstrating the utility of these tools for fishery management.

These statewide data will allow managers to readily perform an initial assessment of the restoration or rehabilitation potential of a site for various fish species. For example, these data could be used to assess thermal effects of the over 2,500 dams or major water discharges that are present on downstream reaches of Michigan rivers. Data on LFY and CA conditions for the Middle
Branch River (a tributary to the Muskegon River in the northcentral Lower Peninsula) at the site of a mill pond in Marion indicated that this river reach should have excellent potential for supporting substantial populations of brown trout (Figure 6). Temperature measurements upstream from the impoundment indicated likewise, but conditions below the impoundment showed substantial warming that would be detrimental to coldwater fishes (Figure 6). These data suggest that proposed management efforts to create a channel bypassing the impoundment (O'Neal 2006) would probably result in good conditions for brown trout in the river downstream from the confluence of the bypass channel and the original river channel.

Fish stocking represents a substantial investment of resources by the MDNR Fisheries Division (FD) as hatcheryrelated operations consume roughly $30 \%$ of the agency's 


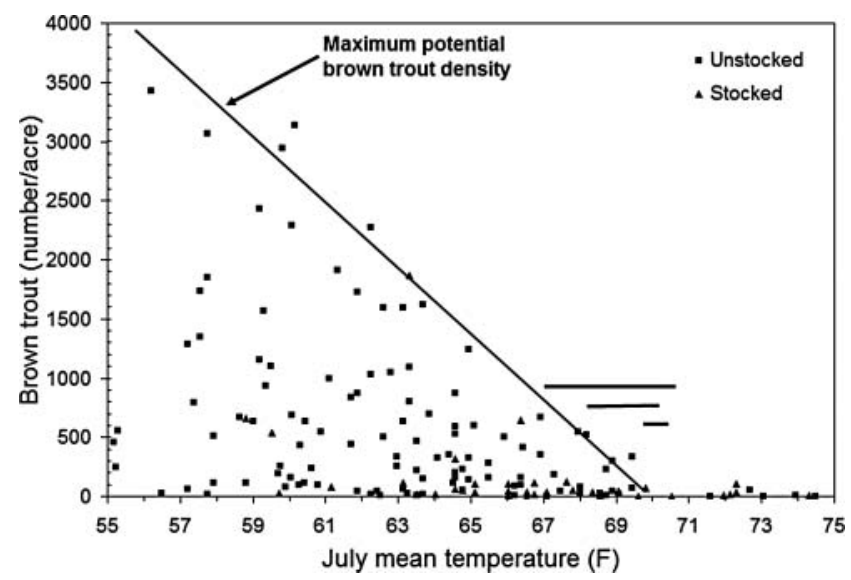

FIGURE 7. Numerical density of brown trout at 152 unstocked (squares) and stocked (triangles) sites on Michigan streams in relation to July mean temperature $\left({ }^{\circ} \mathrm{F}\right)$. The line fitted along the upper portion of the data represents a hypothesized relationship between July mean temperature and the maximum potential brown trout density for Michigan rivers. Zero-density values are not shown. Horizontal lines show the range in mean July temperature from 1998 to 2001 for the Au Sable River below Mio Dam (longest line), the Manistee River below Hodenpyl Dam (medium-length line), and the Muskegon River below Croton Dam (shortest line). Data for the 29 unstocked sites were obtained from status and trends surveys (T. Wills, Michigan Department of Natural Resources and Environment Michigan Department of Natural Resources (MDNRE), Fisheries Division [FD], unpublished data).

budget (MDNR-FD, unpublished data). A good portion of this expense is directed toward the stocking of trout in streams. Our data showed that the mean July temperature (or one of its correlates) can limit a stream's potential to support brown trout density since the maximum observed fish densities generally declined with increasing temperature (Figure 7). A similar relationship occurred between mean July temperature and brook trout density (Figure 8). Such information can be used

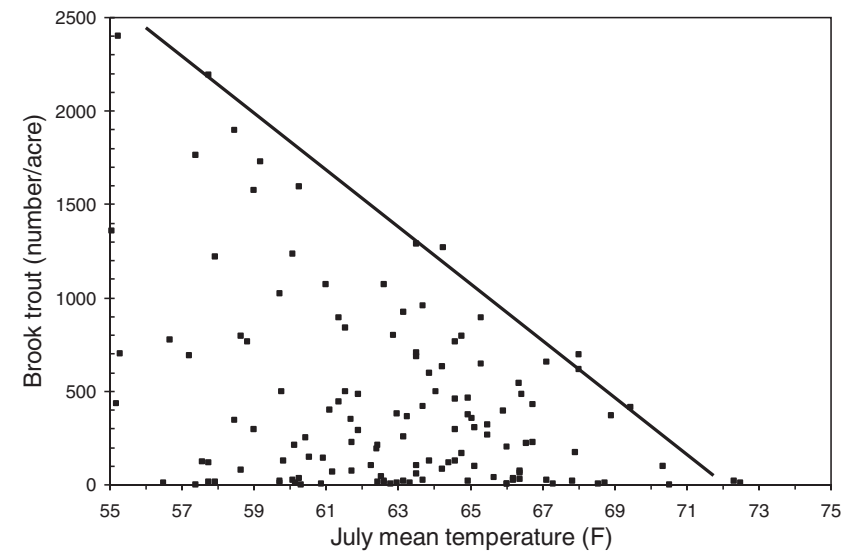

FIGURE 8. Numerical density of brook trout at 139 unstocked sites on Michigan streams in relation to July mean temperature $\left({ }^{\circ} \mathrm{F}\right)$. Zero-density values are not shown. The line fitted along the upper portion of the data represents a hypothesized relationship between July mean temperature and the maximum potential brook trout density for Michigan rivers. Data for 29 sites were obtained from status and trends surveys (T. Wills, MDNRE-FD, unpublished data). to assess a river's potential for sustaining stocked trout. Rivers where temperature conditions are adequate for trout survival (e.g., mean July temperatures consistently at or below $68^{\circ} \mathrm{F}$ ) and where there is no (or very little) natural reproduction of trout could be considered for stocking. Obviously, streams with temperature or LFY conditions that are unsuitable for trout are not good candidates for stocking, while those with marginal conditions will require especially careful evaluation and management.

Our tools can also assist in selecting appropriate sportfishing regulations. For example, contrasting thermal conditions (and resulting coldwater fishery potential) in the large, groundwater-fed, heavily stocked tailwaters of the Au Sable, Manistee, and Muskegon rivers may allow for different management approaches (Figure 7). These tailwaters are among the most expensive stocking sites for nonmigratory salmonids in Michigan. Although these river segments all approach (and sometimes exceed) the statewide thermal ceiling for trout reproduction, they are unique in being both highly groundwater fed and fairly large. Larger water volume limits diurnal water temperature variation (Wehrly et al. 2003); thus, the duration of stressful temperatures is reduced, and stocked trout are able to persist at mean summer water temperatures that are higher than normal (Wehrly et al. 2007; Brenden et al. 2008). Michigan fishery managers are currently using data on thermal characteristics of these reaches to optimize the sport fishery "return" on their stocking investment. For example, lower minimum size limits seem appropriate in reaches such as the Muskegon River below Croton Dam, where thermal conditions periodically limit annual survival (MDNR-FD, unpublished data). Higher size limits are more feasible when thermal constraints are reduced and when fish can survive to larger (sometimes trophy) size. For example, the MDNR-FD is currently experimenting with higher size limits for brown trout in a stocked reach of the Au Sable River below Mio Dam, where summer water temperatures are cooler and where annual survival of stocked fish is high. When summer temperatures are high in thermally marginal segments, access to areas with groundwater inputs can be critical for trout survival (Hayes et al. 1998). An intermediate size limit for brown trout is applied in the Manistee River tailwater, where the potential to support brown trout is in between that of the Au Sable and Muskegon River tailwaters (Figure 7).

The tools we developed are useful for comparing habitat use relationships among species. For example, plots from these data shed light on the usefulness of certain taxa (e.g., mottled sculpin) as indicators of "coldwater" stream conditions and their subsequent use in justifying trout stocking. Our data show higher thermal tolerances for mottled sculpin relative to salmonids, suggesting that mottled sculpin presence is not necessarily an indicator of a stream that would be highly suited to salmonids (Figure 6). Similarly, our analyses support work done by Moyle et al. (1983), suggesting that large populations of white suckers and low populations of trout may be more indicative of stream temperature conditions that are marginal for trout (Figures 3, 


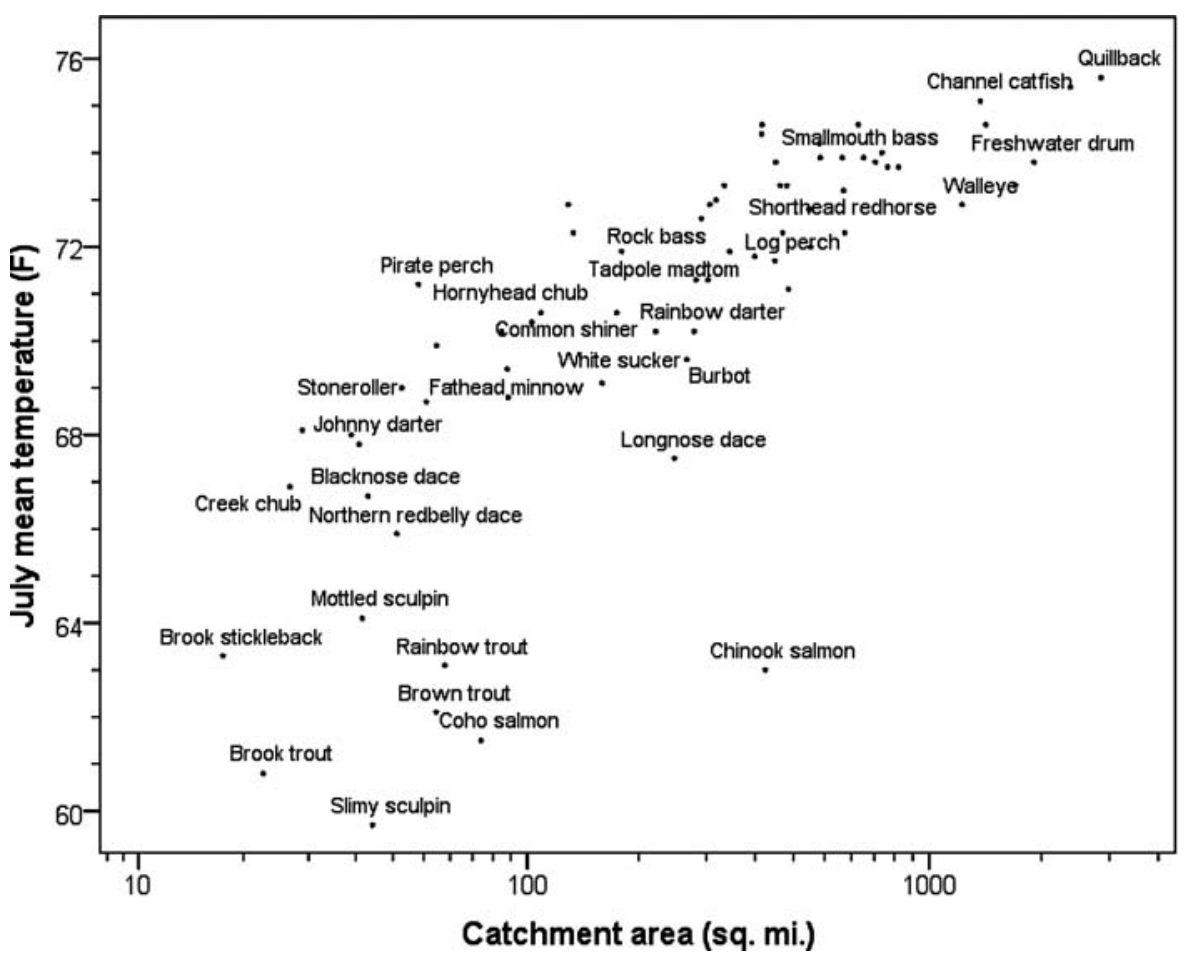

FIGURE 9. July mean temperature $\left({ }^{\circ} \mathrm{F}\right)$ and catchment area $\left(\mathrm{mi}^{2}\right)$ values of "optimal" sites (i.e., sites at which abundance was highest) for 68 common fishes in Michigan rivers. Common names of select fishes are shown in the vicinity of their optimal values; the other fishes are listed in Table 1.

4) than of competition between trout and white suckers. Such relationships support the position that chemical reclamations in marginal trout streams should be limited.

The tools built from these data also provide insight into habitat affinities of many Michigan fish species for which habitat requirements are not well understood. For example, smallmouth bass are very popular game fish in warmwater rivers, but before these models were available we had little information on their abundance patterns in the state's rivers. With data from hundreds of surveys demonstrating that high smallmouth bass densities are limited to rivers having CAs of $500 \mathrm{mi}^{2}$ or more (Figure 4), managers will have strong empirical support for avoiding attempts to develop smallmouth bass fisheries in the state's small rivers or streams. We also used these data to plot CA and July mean temperature conditions under which common Michigan fish species are most abundant (Figure 9); this information can provide managers with the means for quantitatively comparing differences in preferred habitats of Michigan fishes. Using the requisite LFY, CA, and July water temperature data, we developed variance-based spreadsheet models (Zorn et al. 2009) that can be used to provide rough estimates of fish community structure in any Michigan stream reach. These models may aid in projecting fish community structure in reaches where fish kills or other disruptive events have occurred or are ongoing. Since the models are built from a statewide database, they are applicable to most types of rivers in Michigan. The models and related fish assemblage classifications (e.g., Zorn et al. 2002;
Wehrly et al. 2003) have been used to provide fish community attribution for statewide river valley segment classification and inventory projects (e.g., Seelbach et al. 2006). Data on these segment-specific characteristic or target fish assemblages have various potential uses for conservation planning and education (e.g., Wiley et al. 1998; Zorn et al. 2008; Bain, in press).

Data relating fish densities to LFY also provide a useful basis for assessing the influence of low-flow water withdrawal on fishes. Reduced LFY values (and associated increased temperatures) due to water withdrawal would lower the potential of some stream reaches for trout, especially those that currently provide thermally marginal conditions for trout reproduction and survival. For example, reducing the LFY of the Iron River at the Upper Peninsula city of Iron River from its current value to $0.2 \mathrm{ft}^{3} \cdot \mathrm{s}^{-1} \cdot \mathrm{mi}^{-2}$ would probably make the stream ill-suited for brook trout (Figure 4). Likewise, diminishing the LFY of the Middle Branch River at Marion from its current value to $0.05 \mathrm{ft}^{3} \cdot \mathrm{s}^{-1} \cdot \mathrm{mi}^{-2}$ might severely reduce its capacity to support self-sustaining brown trout populations (Figure 6). Thermally marginal coldwater streams may be most obviously affected by water withdrawal, but such effects are probably not limited to these streams. For a given size of stream, densities of many coolwater and warmwater species similarly declined with reductions in LFY (Figure 5), indicating that these species would also be detrimentally affected by water withdrawal. Further analysis of LFY, CA, July water temperature, fish survey, and additional data led to the development of a model for projecting fish 
community responses to the reduced LFYs and increased temperatures associated with summer water withdrawal (Zorn et al. 2008). This model was used to support groundwater protection legislation that was recently passed in Michigan (Hamilton and Seelbach 2010).

\section{Limitations}

The strength of our findings rests on the breadth of habitat conditions in Michigan and the hundreds of surveys that went into building the relationships we present. The breadth of our sample underlies the power of the analysis, which results in plots that show conditions where a species would thrive and where it would be unlikely to do well. Still, the findings of this study and the utility of our results are limited in several ways. Despite the large number of sites included in this study, relatively few data (i.e., $n<10$ ) were available for certain combinations of LFY, CA, or July temperature conditions (Figure 2). Sometimes this occurred due to a lack of samples for a particular type of stream, while at other times it resulted from a lack of these stream types in Michigan (e.g., streams with CA $>600 \mathrm{mi}^{2}$ and LFY $>0.6$ $\mathrm{ft}^{3} \cdot \mathrm{s}^{-1} \cdot \mathrm{mi}^{-2}$ ). Inadequate data could result in misrepresentation of the range of suitable conditions for a species and cause plots of LFY-CA versus fish density for some species to exhibit several peaks rather than a smooth surface with a single peak representing optimal conditions. Minor variation in peaks might also be attributed to the manner in which data were stratified for summarization and plotted. The most pronounced example of distinct peaks that might have resulted from limited sample size or data stratification effects occurred for the set of streams with CA values of 250-600 $\mathrm{mi}^{2}$ and LFY values of $0.05-0.10 \mathrm{ft}^{3} \cdot \mathrm{s}^{-1} \cdot \mathrm{mi}^{-2}$. Of the six sites that met these criteria and for which fish density data were available, three were on the Maple River. The Maple River is a tributary to the Grand River that flows within an extremely low-gradient former glacial drainageway (i.e., the valley is much larger than the present river) and supports large populations of lake fishes (Figure 5). The low sample size and unique nature of the Maple River resulted in discrete density peaks for nine species, including the black crappie, bluegill, bowfin, common carp, channel catfish, flathead catfish, largemouth bass, pumpkinseed, tadpole madtom, and white crappie (species plots occur in Zorn et al. 2009). Broad patterns showing the general relation between habitat conditions and species density often still occurred, but such instances of multiple peaks probably reflect sampling inadequacies.

Errors or biases associated with data collection or model prediction could limit the accuracy of the relationships we described. The $90 \%$ exceedance flow values were often predicted, and temperature values were estimated when measurements were not available. Inaccuracies associated with these predictions were introduced into the analysis. However, we tried to minimize such errors by excluding known problem sites, such as a set of very small (i.e., $\mathrm{CA}<6 \mathrm{mi}^{2}$ ) trout streams we identified as having biased flow predictions (Zorn et al. 2002). Catchment area values, fish densities, and most temperatures were measured, so there is probably little error for these vari- ables except error due to fish misidentification or collection of temperature data that were not representative of average conditions. Finally, our fish abundance data were limited to summer collections, so the resulting plots do not represent year-round densities for species that show strong seasonal migrations or variation in density levels (e.g., Chinook salmon, coho salmon, and rainbow trout).

In this study, we focused on limiting variables and dominant trends rather than on mechanisms and explaining variation. For example, our wedge-shaped scatter plots of trout density versus temperature (Figures 7,8) show when temperature limits fish abundance, but they do not identify other factors that could limit fish density beyond the thermal constraints of the stream (Terrell et al. 1996; Thompson et al. 1996). Likewise, anthropogenic effects on fish abundance in Michigan streams were not specifically examined in this study but were explored in a previous study (Zorn et al. 2004). Anthropogenic stressors, which are typically greatest in the southern half of the state, probably resulted in conditions favoring tolerant species over intolerant ones.

With the fish density surface plots, we attempted to show dominant relations between species density and habitat conditions by averaging measured values across groups of similar sites and by using "dominant" habitat drivers (Zorn et al. 2002). Our results do not show the amount of variation in conditions or fish density that occurs within each group of sites. Habitat and fish density values were simply averaged and plotted for each subset of sites that met particular habitat criteria. This is illustrated by comparing the range of individual site conditions (Figure 2) with the range of average values plotted (e.g., Figures $4,6)$. As a result, conditions of some sites (e.g., the Manistee River in Figure 5) now appear to lie off the surface of the graph. In such cases, it is usually appropriate to extrapolate the observed fish density trend beyond the shaded surface of the plot to the site's conditions.

The objective of developing straightforward, data-driven products limits the application of our results to basic decisionsupport uses. Although multivariate modeling approaches would certainly have explained more variation in species abundances, we limited our summaries to simple, visual, easily communicated plots of fish abundance data and dominant driving variables. Despite these shortcomings, our experience with Michigan Department of Natural Resources and Environment (MDNRE) FD managers and the public indicate that such simple, data-driven decision-support tools will prove quite useful.

\section{Broader Application of the Modeling Approach}

We believe that the approach of using LFY, CA, and July temperature as axes for contrasting streams and displaying fish abundance patterns is widely applicable. The fish-habitat relationships we developed are most applicable to Michigan but may also apply to adjacent glaciated regions. This seems especially true for relationships between fish abundance and July temperature, which are more directly tied to fish bioenergetics than are relationships for LFY and CA (Zorn et al. 2002). The 
applicability of our specific LFY-CA-based plots to other regions may be limited due to differences in relationships between fish density and driving variables that determine local habitat conditions (e.g., climate, latitude, altitude, and watershed geology). Still, we think our general approach could be used in other regions to develop parallel models that relate fish density to key habitat variables. In addition, the Michigan plots can serve as initial hypotheses for comparison with the fish-habitat relationships developed in other regions.

In the following paragraphs, we provide broad guidance for those seeking to develop similar tools in their region. The "simple" relationships presented in this study are a culmination of many years of literature review, thought, coordinated data assembly, data collection, and modeling effort. The present study and related projects grew from a study (i.e., the MRI) initiated in the 1980s by the MDNRE-FD and the University of Michigan to inventory and classify Michigan rivers. The goals of the MRI were to understand and predict the distribution and abundance patterns of aquatic organisms and to provide information that could guide the management of river habitats and biota (Seelbach and Wiley 1997; Wiley and Seelbach 1997). Despite Michigan's relatively flat landscape, it was often difficult to predict what was in adjacent streams. The scant literature available in the 1980s (e.g., Hendrickson and Doonan 1972; T. C. Dewberry, Gutenberg College, unpublished) indicated tremendous spatial variation in hydrologic conditions across Michigan streams and suggested key linkages among surficial geology, hydrology, LFY, CA, water temperature, other instream conditions, and biota. This led to an initiative to develop models for predicting annual exceedance flow values for Michigan streams by using the U.S. Geological Survey streamflow data and GISbased data layers (Seelbach et al. 2010). Similarly, another effort focused on models to predict July stream temperature conditions from field-based temperature measurements and GIS data layers (Wehrly et al. 1997). Subsequent analyses confirmed that water temperatures, summer flow yields, catchment size, substrate, and factors influencing these variables were key to predicting the distribution and abundance of populations of common Michigan stream fishes (Zorn et al. 2002, 2004; Wehrly et al. 2003). Other factors, such as zoogeography and biotic interactions, were important in predicting the distribution and abundance of populations of some species but had less explanatory power overall (Zorn et al. 2004).

Researchers interested in developing management tools for other regions should explore and ultimately understand the key processes shaping fish communities in their area through literature- and empirical-based investigative research. As a first step, we suggest that investigators focus on variables believed to be energetically linked to fish growth, survival, and reproduction (e.g., water temperature, dissolved oxygen, substrate, and velocity). Attention should then be given to factors (e.g., climate, geology, or topography) that control the variables hypothesized as having the strongest influences on fish distribution and abundance patterns in the region. In regions where flow or water temperature conditions do not influence fish densities, models may be needed to predict values of other key variables. Other approaches may be required for situations where biological interactions are key factors affecting fish density patterns. For example, we found it difficult to conclusively identify negative effects of brown trout density on brook trout density based on multiple linear regression models (Zorn et al. 2004), but strong biotic effects were demonstrated when indirect effects were accounted for with structural equation models (Zorn and Wiley 2010).

The next step would involve assembling existing fish community survey data into a relational database. If data are not housed at a central location, this step might involve traveling to various offices to access hard copies of survey data. Field-based fish and habitat survey data would then be linked to GIS-based measured and modeled habitat variables for the same site reach, as was done in our study; databases in recent projects have been linked by confluence-to-confluence stream reaches as opposed to individual sites. In our study, these efforts consumed many hours of work by biologists, technicians, and graduate students for several years. The resulting analysis file will enable initial exploration of the data and provide an excellent guide for identifying data gaps to target for future surveys. Fish density models in our study (Zorn et al. 2004; Steen et al. 2008) were based on population estimate data, but we have found that relative abundance (catch per unit effort) data are often adequate for such analyses (Lyons 1996; Zorn et al. 2008).

Once the fish and habitat data are finally assembled, considerable effort should be spent on analyzing and exploring the data from different perspectives. For example, we put much of our effort toward analyses at the fish species level (rather than metrics) since species are distinct ecological entities and are of greatest interest to the public. In addition, we reasoned that predictions from species-based models could be combined in any number of ways to produce metrics. An underlying objective of our fish abundance modeling was to focus on mechanisms, driving variables, and fairly straightforward relationships as much as possible since we often interact with the various agency personnel, legislators, anglers, nonprofit organizations, and the public. Correspondingly, we focused on models with relatively simple structure (e.g., plots with three or fewer variables, statistical summaries, and variance-based spreadsheet models). In addition to producing tools that were generally robust and broadly applicable, this approach allowed us to develop an intuitive understanding of relationships among variables within the data set. We encourage ecologists to consider their audiences when conducting such analyses and to avoid underestimating the utility of "simple" summaries and models, as we have found them to be highly useful in Michigan.

\section{ACKNOWLEDGMENTS}

Numerous crews from the MDNR, U.S. Department of Agriculture Forest Service, University of Michigan, and Michigan 
State University collected the field data. Many former University of Michigan students contributed data to this study, namely Matthew Baker, John Fay, Dana Infante, Catherine Riseng, and Kevin Wehrly. James Gapczynski (MDNR-IFR) performed initial entry of fisheries data in MRI databases. James Schneider, Philip Schneeberger, and Chris Freiburger provided thoughtful advice and manuscript reviews. We acknowledge Richard Clark (MDNR-IFR) for administrative support, and Ellen Johnston and Alan Sutton (MDNR-IFR) for assistance in preparation of this manuscript. This research was supported with funds from the Federal Aid in Sport Fish Restoration Act (Study 680, Project F-81-R, Michigan), MDNR-FD, and the Michigan Professional Employees Society.

\section{REFERENCES}

Aadland, L., and A. Kuitunen. 2006. Habitat suitability criteria for stream fishes and mussels of Minnesota. Minnesota Department of Natural Resources, Special Publication 162, St. Paul.

Bailey, R. M., W. C. Latta, and G. R. Smith. 2004. An atlas of Michigan fishes with keys and illustration for their identification. University of Michigan, Museum of Zoology, Miscellaneous Publication 192, Ann Arbor.

Bain, M. B. In press. Target fish communities for restoration of waterways supporting society and nature. Journal of Applied Ichthyology.

Baker, E. A. 2006. A landscape-based ecological classification for river valley segments in Michigan's Upper Peninsula. Michigan Department of Natural Resources, Fisheries Research Report 2085, Ann Arbor.

Baker, M. E., M. J. Wiley, M. L. Carlson, and P. W. Seelbach. 2003. A GIS model of subsurface water potential for aquatic resource inventory, assessment, and environmental management. Environmental Management (New York) 32:706-719.

Brenden, T. O., R. D. Clark Jr., A. R. Cooper, P. W. Seelbach, L. Wang, S. S. Aichele, E. G. Bissell, and J. S. Stewart. 2006. A GIS framework for collecting, managing, and analyzing multiscale landscape variables across large regions for river conservation and management. Pages 49-74 in R. M. Hughes, L. Wang, and P. W. Seelbach, editors. Influences of landscapes on stream habitats and biological assemblages. American Fisheries Society, Symposium 48, Bethesda, Maryland.

Brenden, T. O., L. Wang, and P. W. Seelbach. 2008. A river valley segment classification of Michigan streams based on fish and physical attributes. Transactions of the American Fisheries Society 137:1621-1636.

Brett, J. R. 1979. Environmental factors and growth. Pages 599-675 in W. S. Hoar, D. L. Randall, and J. R. Brett, editors. Fish physiology: volume VIII. Academic Press, New York.

Degerman, E., and B. Sers. 1993. A study of interactions between fish species in streams using survey data and the PCA-hyperspace technique. Nordic Journal of Freshwater Research 68:5-13.

Fausch, K. D., C. L. Hawkes, and M. G. Parsons. 1988. Models that predict standing crop of stream fish from habitat variables: 1950-1985. U.S. Forest Service General Technical Report PNW-GTR-213.

Gido, K. B., J. A. Falke, R. M. Oakes, and K. J. Hase. 2006. Fish-habitat relations across spatial scales in prairie streams. Pages 265-285 in R. M. Hughes, L. Wang, and P. W. Seelbach, editors. Influences of landscapes on stream habitats and biological assemblages. American Fisheries Society, Symposium 48, Bethesda, Maryland.

Hamilton, D. A., and P. W. Seelbach. 2010. Determining environmental limits to streamflow depletion across Michigan, volume 42. Pages 534-537 in A. S. Wall, editor. The book of the states, 2010 edition. The Council of State Governments, Lexington, Kentucky.

Hayes, D. B., W. W. Taylor, M. T. Drake, S. M. Marod, and G. E. Whelan. 1998. The value of headwaters to brook trout (Salvelinus fontinalis) in the Ford River, Michigan, USA. Pages 175-185 in M. J. Haigh, J. Krecek, G. S.
Rajwar, and M. P. Kilmartin, editors. Headwaters: water resources and soil conservation. Oxford and IBH Publishing, New Delhi.

Hendrickson, G. E., and C. J. Doonan. 1972. Hydrology and recreation on the cold-water rivers of Michigan's southern peninsula. U.S. Geological Survey and Michigan Geological Survey, Water Information Series, Report 3, Lansing.

Hynes, H. B. N. 1972. The ecology of running waters. University of Toronto Press, Buffalo, New York.

Lamouroux, N., J. M. Olivier, H. Persat, M. Pouilly, Y. Souchon, and B. Statzner. 1999. Predicting community characteristics from habitat conditions: fluvial fish and hydraulics. Freshwater Biology 42:275-299.

Lyons, J. 1996. Patterns in the species composition of fish assemblages among Wisconsin streams. Environmental Biology of Fishes 45:329-341.

Magnuson, J. J., L. B. Crowder, and P. A. Medvick. 1979. Temperature as an ecological resource. American Zoologist 19:331-343.

Meisner, J. D., J. L. Goodier, H. A. Regier, B. J. Shuter, and W. J. Christie. 1987. An assessment of the effects of climate warming on Great Lakes basin fishes. Journal of Great Lakes Research 13:340-352.

Meisner, J. D., J. S. Rosenfeld, and H. A. Regier. 1988. The role of groundwater in the impact of climate warming on stream salmonids. Fisheries 13(3):2-8.

Moyle, P. B., B. Vondracek, and G. D. Grossman. 1983. Responses of fish populations in the north fork of the Feather River, California, to treatments with fish toxicants. North American Journal of Fisheries Management 3:4860.

O'Neal, R. P. 2006. Evaluation of the fish community and related ecological features of the Middle Branch River, Osceola County. Michigan Department of Natural Resources, Fisheries Technical Report TR2006-1, Ann Arbor.

Poff, N. L., and J. D. Allan. 1995. Functional organization of stream fish assemblages in relation to hydrologic variability. Ecology 76:606-627.

Poff, N. L., and J. V. Ward. 1989. Implications of streamflow variability and predictability for lotic community structure: a regional analysis of streamflow patterns. Canadian Journal of Fisheries and Aquatic Sciences 46:1805-1818.

Rabeni, C. F., and S. P. Sowa. 1996. Integrating biological realism into habitat restoration and conservation strategies for small streams. Canadian Journal of Fisheries and Aquatic Sciences 53(Supplement 1):252-259.

Rahel, F. J., and W. A. Hubert. 1991. Fish assemblages and habitat gradients in a Rocky Mountain-Great Plains stream: biotic zonation and additive patterns of community change. Transactions of the American Fisheries Society 120:319-332.

Raleigh, R. F., L. D. Zuckerman, and P. C. Nelson. 1986. Habitat suitability index models and instream flow suitability curves: brown trout, revised. U.S. Fish and Wildlife Service Biological Report 82(10.124).

Seelbach, P. W., L. C. Hinz, M. J. Wiley, and A. R. Cooper. 2010. Use of multiple linear regression to estimate flow regimes for all rivers across Illinois, Michigan, and Wisconsin. Michigan Department of Natural Resources and Environment, Fisheries Research Report 2095, Ann Arbor.

Seelbach, P. W., R. N. Lockwood, and J. R. Ryckman. 1994. Efficiency of sampling river fishes with rotenone. Michigan Department of Natural Resources, Fisheries Research Report 2009, Ann Arbor.

Seelbach, P. W., G. L. Towns, and D. D. Nelson. 1988. Guidelines for sampling warmwater rivers with rotenone. Appendix 17 in J. W. Merna, editor. Manual of fisheries survey methods. Michigan Department of Natural Resources, Fisheries Management Report 9, Ann Arbor.

Seelbach, P. W., and M. J. Wiley. 1997. Overview of the Michigan rivers inventory project. Michigan Department of Natural Resources, Fisheries Technical Report 97-3, Ann Arbor.

Seelbach, P. W., M. J. Wiley, M. E. Baker, and K. E. Wehrly. 2006. Initial classification of river valley segments across Michigan's Lower Peninsula. Pages 25-48 in R. M. Hughes, L. Wang, and P. W. Seelbach, editors. Influences of landscapes on stream habitats and biological assemblages. American Fisheries Society, Symposium 48, Bethesda, Maryland.

Smale, M. A., and C. F. Rabeni. 1995a. Hypoxia and hyperthermia tolerances of headwater stream fishes. Transactions of the American Fisheries Society 124:698-710. 
Smale, M. A., and C. F. Rabeni. 1995b. Influences of hypoxia and hyperthermia on fish species composition in headwater streams. Transactions of the American Fisheries Society 124:711-725.

Stanfield, L. W., S. F. Gibson, and J. A. Borwick. 2006. Using a landscape approach to identify the distribution and density patterns of salmonids in Lake Ontario tributaries. Pages 601-621 in R. M. Hughes, L. Wang, and P. W. Seelbach, editors. Influences of landscapes on stream habitats and biological assemblages. American Fisheries Society, Symposium 48, Bethesda, Maryland.

Steen, P. J., T. G. Zorn, P. W. Seelbach, and J. S. Schaeffer. 2008. Classification tree models for predicting distributions of Michigan stream fish from landscape variables. Transactions of the American Fisheries Society 137:976996.

Terrell, J. W., B. S. Cade, J. Carpenter, and J. M. Thompson. 1996. Modeling stream fish habitat limitations from wedge-shaped patterns of variation in standing stock. Transactions of the American Fisheries Society 125:104-117.

Thompson, J. D., G. Weiblen, B. A. Thomson, S. Alfaro, and P. Legendre. 1996. Untangling multiple factors in spatial distributions: lilies, gophers, and rocks. Ecology 77:1698-1715.

Waite, I. R., and K. D. Carpenter. 2000. Associations among fish assemblage structure and environmental variable in the Willamette Basin streams, Oregon. Transactions of the American Fisheries Society 129:754-770.

Wehrly, K. E., L. Wang, and M. Mitro. 2007. Field-based estimates of thermal tolerance limits for trout: incorporating exposure time and temperature fluctuation. Transactions of the American Fisheries Society 136:365374

Wehrly, K. E., M. J. Wiley, and P. W. Seelbach. 1997. Landscape-based models that predict July thermal characteristics of lower Michigan rivers. Michigan Department of Natural Resources, Fisheries Research Report 2037, Ann Arbor.

Wehrly, K. E., M. J. Wiley, and P. W. Seelbach. 2003. Classifying regional variation in thermal regime based on stream fish community patterns. Transactions of the American Fisheries Society 132:18-38.

Wiley, M. J., S. L. Kohler, and P. W. Seelbach. 1997. Reconciling landscape and local views of aquatic communities: lessons from Michigan trout streams. Freshwater Biology 37:133-148.
Wiley, M. J., and P. W. Seelbach. 1997. An introduction to rivers- the conceptual basis for the Michigan rivers inventory (MRI) project. Michigan Department of Natural Resources, Fisheries Special Report 20, Ann Arbor.

Wiley, M. J., P. W. Seelbach, and S. P. Bowler. 1998. Ecological targets for rehabilitation of the Rouge River. Rouge Project Office, Special Report RPOPI-SR21.00, Wayne County, Michigan.

Zippin, C. 1958. The removal method of population estimation. Journal of Wildlife Management 22:82-90.

Zorn, T. G., P. W. Seelbach, E. S. Rutherford, T. C. Wills, S. Cheng, and M. J. Wiley. 2008. A landscape-scale habitat suitability model to evaluate effects of flow reduction on fish assemblages in Michigan streams. Michigan Department of Natural Resources, Fisheries Research Report 2089, Ann Arbor.

Zorn, T. G., P. W. Seelbach, and M. J. Wiley. 2002. Distributions of stream fishes and their relationship to stream size and hydrology in Michigan's lower peninsula. Transactions of the American Fisheries Society 131:70-85.

Zorn, T. G., P. W. Seelbach, and M. J. Wiley. 2004. Utility of species-specific, multiple linear regression models for prediction of fish assemblages in rivers of Michigan's lower peninsula. Michigan Department of Natural Resources, Fisheries Research Report 2072, Ann Arbor.

Zorn, T. G., P. W. Seelbach, and M. J. Wiley. 2009. Relationships between habitat and fish density in Michigan streams. Michigan Department of Natural Resources and Environment, Fisheries Research Report 2091, Ann Arbor. Available: www.michigandnr.com/PUBLICATIONS/ PDFS/ifr/ifrlibra/Research/reports/2091/RR2091.pdf. (April 2010).

Zorn, T. G., and S. P. Sendek. 2001. Au Sable River assessment. Michigan Department of Natural Resources, Fisheries Special Report 26, Ann Arbor.

Zorn, T. G., and M. J. Wiley. 2006. Influence of landscape characteristics on local habitat and fish biomass in streams of Michigan's Lower Peninsula. Pages 375-394 in R. M. Hughes, L. Wang, and P. W. Seelbach, editors. Influences of landscapes on stream habitats and biological assemblages. American Fisheries Society, Symposium 48, Bethesda, Maryland.

Zorn, T. G., and M. J. Wiley. 2010. Influence of sampling extent on the relative importance of biotic and abiotic factors in explaining variation in stream fish density. Pages 487-502 in K. Gido and D. Jackson, editors. Community ecology of stream fishes: concepts, approaches, and techniques. American Fisheries Society, Symposium 73, Bethesda, Maryland. 